\title{
Shrines and Schools in Byzantine Cappadocia
}

\begin{abstract}
Elena Ene D-Vasilescu
University of Oxford

Abstract:

This article has two distinct sections: one refers to churches (i) and one to schools (ii) in Byzantine Cappadocia. Between the fifth and the eleventh centuries the churches in this province of the Empire were not only the places where the Liturgy was performed, but also the social and spiritual centres of villages, towns, army garrisons, monastic complexes, etc. They fulfilled the same specific functions regardless of the purpose and scale concerning the settlements in which they were located. The paper provides evidence to illustrate what these functions were and, to some extent, by which means they were accomplished

It also presents some suggestions with respect to the physical appearance of schools in the area. By doing so it allows plausible generalizations regarding the layout of other educational establishments throughout the Empire. As known, there has not been substantial material published on this subject in the field of Byzantine Studies and any contribution made on this topic should be welcome.
\end{abstract}

\section{$\underline{\text { Shrines and Schools in Byzantine Cappadocia }}$}

As a consequence of various debates regarding the paintings in the cave-churches of

Cappadocia, these shrines "were eventually disassociated from their wider social and physical context". ${ }^{1}$ One needs to examine them within their environment, so if Veronica G. Kalas's above-mentioned statement is true, an intellectual 're-association', i.e. re-contextualisation, is necessary. I hope this paper can contribute towards such a studious process; it intends to emphasize the way churches - but also schools - in this region of Anatolia were a part of their milieu and to fathom the functions they played in their communities between the fifth and the eleventh centuries, the time when the area was under Byzantine governance. ${ }^{2}$ By

\footnotetext{
${ }^{1}$ Veronica G. Kalas, "Early Explorations of Cappadocia and the Monastic Myth", in Byzantine and Modern Greek Studies 28, 2004, p. 101.

${ }^{2}$ As known, Caesarea was conquered by the Seljuks in 1082 . We find this information, for instance in Nicole Thierry, La Cappadoce de l'antiquité au Moyen Âge, Brepols, Turnhout (Bibliothèque de l'Antiquité tardive 4), 2002, pp. 315-316. Even after this moment, the churches, especially in villages, still kept their roles - though manifested on a smaller scale - until all or most of them were closed on the occasion of the exchange of population between Greece and Turkey in 1923.
} 
doing so, it seeks mainly to organize in a different way some of the information about Cappadocia published so far, to communicate some of the ideas amassed during a visit I made in the area, to publish several photographs from those I took while there, and perhaps most importantly, to offer some intimations about how the physical setting of schools in this province of the empire would have been.

The text refers in its first part to Cappadocian shrines and comments on schools in its second.

\section{i) Churches}

The main thesis of this article is that, regardless of the purpose of the settlements to which they belonged (villages and towns, monasteries, military bases, etc.), the churches in Cappadocia maintained their role as hubs of communities throughout the Byzantine presence in the land. They were the most stable element within a changing landscape and that fact was instrumental in the survival of the people who inhabited it. These shrines were either centres of monasteries or parochial churches. I tend to think that at least some of them were simultaneously both: based on the scarce information provided by the literature (we shall expand on this topic later $)^{3}$ and on the present-day practice, one can assume that a church belonging to a monastery could have served the needs of the closest town(s) and village(s) as well). I have included military chapels in the category of parochial/lay places of worship.

To facilitate the discussion about churches in Cappadocia, a map of this area and of its complexes of habitation has been inserted below (fig. 1).

\footnotetext{
${ }^{3}$ Athanasios Markopoulos, "Education", in Elizabeth Jeffreys, John F Haldon and Robin Cormack, The Oxford handbook of Byzantine studies, Oxford Handbooks in Classics and Ancient History, Oxford: Oxford University Press, 2008, p. 788 [pp. 785-795].
} 


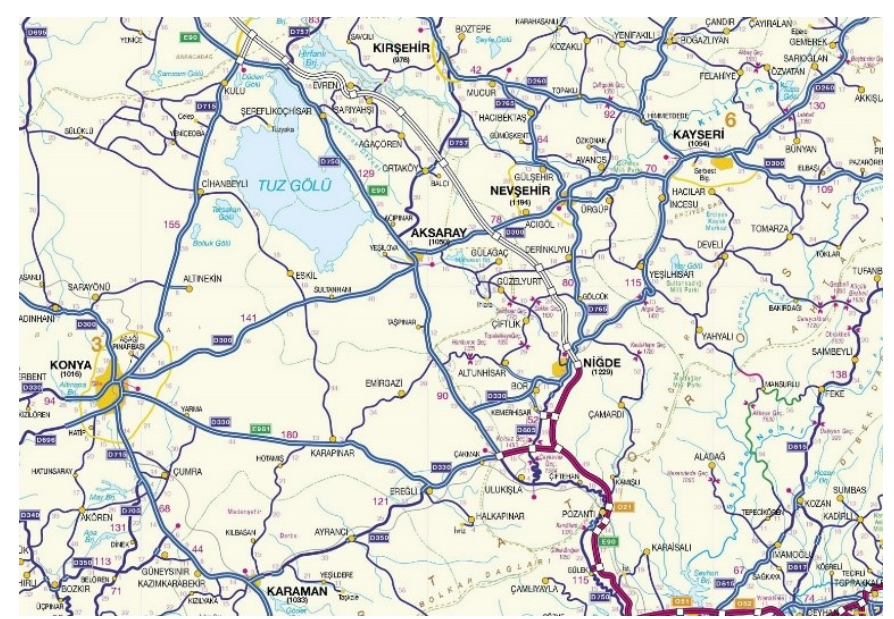

Fig. 1. Contemporary map of Cappadocia; mapofmap1.wordpress.com; the access to this map is licensed under the Creative Commons Attribution 2.0 Generic.

A good example to prove such a situation of multi-functionality is the church within Selime Kale Kalesi (Castle/fortress; locally also called 'the Cathedral within the fortress') in Peristrema/Belistrma Valley, Western Cappadocia. This is described by, among others, Robert G. Ousterhout, ${ }^{4}$ Lyn Rodley, ${ }^{5}$ and Catherine Jolivet-Lévy. ${ }^{6}$ The large settlement was a religious site (it has, indeed, only a church, but this is vast), a place of rest for merchants who operated as far as to trade clusters along the Silk Road, and also an administrative and military centre ${ }^{7}$; it was founded in either the eight-ninth centuries ${ }^{8}$ or tenth-eleventh centuries $^{9}$ (sources differ as to the date). The spacious church at the east of the site [the

\footnotetext{
${ }^{4}$ Robert G. Ousterhout, Visualizing Community: Art, Material Culture, and Settlement in Byzantine Cappadocia, Dumbarton Oaks Studies 46, Washington D.C.: Dumbarton Oaks Research Library and Collection and Harvard University Press, 2017, pp. 81, 163, 179-80; 335-41, 490, and A Byzantine Settlement in Cappadocia, Dumbarton Oaks Studies 42, Washington, D.C.: Dumbarton Oaks Research Library and Collection and Harvard University Press, revised edition 2011, pp. 142, 149, 151-3, 162, 165, 167-8.

${ }^{5}$ Lyn Rodley, Cave Monasteries of Byzantine Cappadocia, Cambridge University Press, Cambridge, 1985; paper edition 2010.

${ }^{6}$ Catherine Jolivet-Lévy, Les églises byzantines de Cappadoce: le programme iconographique de l'abside et de ses abords, Paris: Éditions du Centre national de la Recherche scientifique CNRS, 1991, pp. 331-332.

${ }^{7}$ Ousterhout, Visualizing Community, pp. 335-341, 490. He provides information about the military presence in Cappadocia in a few places throughout the book.

${ }^{8} \mathrm{~N}$. Thierry, La Cappadoce de l'antiquité.

${ }^{9}$ This is maintained, for instance, by Ousterhout; Visualizing Community, p. 335; there he mentions L. Rodley's dating without any critical comment, so it is to be assumed that he agrees with it. Rodley states that "Selime Kalesi was probably in use for longer than most of the courtyard monasteries, which perhaps supports a tenthcentury foundation date"; see her book Cave Monasteries, p. 85. C. Jolivet-Lévy maintains the same date in Les églises byzantines de Cappadoce, p. 332 and footnote 8 on the same page. Additionally she refers to Jacqueline Lafontaine-Dosogne, who gives the tenth century as the time when the paintings were accomplished. JolivetLévy also indicates that Marcel Restle considers both the establishment of the site and the painting as pertaining to the tenth-eleventh centuries.
} 
actual 'cathedral' that gave the name to the place itself], would have welcomed the local inhabitants as well as people involved in trade, soldiers, believers from neighbourhood, travellers (most of them on the way to Caesarea), pilgrims, diplomats, ${ }^{10}$ and everyone else who wanted to participate in the services carried out within; therefore, the attendees would have been numerous. It is known that: "Byzantine Christians went to church as a matter of course". ${ }^{11}$ An image showing the west side of what Rodley has called Room 13 within the structure at Selime is shown in fig. $2 .^{12}$

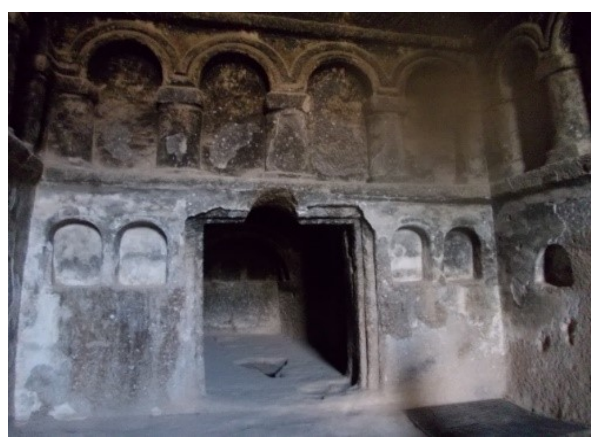

Fig. 2. Selime basilica; photograph of the west side of room 13. Most of the carving and frescoes date to the tenth-eleventh century ${ }^{13}$; photo taken by the author of the article (E. E. D-V) in May 2015. All photographs in the article have been taken by its author, unless otherwise specified.

In his research Hans Rott, who was first to photograph the basilica, covered both the early Christian and Byzantine as well as Seljuk periods of Selime Kalesi. ${ }^{14}$

The situation regarding the complex at Çanlı Kilise, the main subject of Ousterhout's book A Byzantine Settlement, provides another good example as to how churches served their communities. ${ }^{15}$ The site is described (part of the account also applies to Selime) as containing mansions, churches, chapels, monasteries, storerooms, refectories, cisterns, shacks, barns,

\footnotetext{
${ }^{10}$ One of these diplomats on behalf of the Church was George Hagiorites the Georgian, who travelled towards Caesarea and stopped in Selime for a while in 1059; Ousterhout, Visualizing Community, p. 480.

${ }^{11}$ Ousterhout, Visualizing Community, p. 480.

12 Rodley, Cave Monasteries..., pp. 77-79.

${ }^{13}$ C. Jolivet-Lévy, Les églises byzantines de Cappadoce, p. 332 and footnote 8 on p. 332; she mentions Jacqueline Lafontaine-Dosogne, who gives this dating concerning the paintings and Marcel Restle, who considers both the establishment of the site and the painting as pertaining to the tenth-eleventh centuries. ${ }^{14}$ Hans Rott, Kleinastische Denmäler aus Pisidien Pamphylien, Kappadokien, Lykien, Leipzig: Studien über christl. Denkmaler 5, 6, 1908.

${ }^{15}$ Ousterhout, A Byzantine Settlement in Cappadocia, Washington, D.C.: Dumbarton Oaks Research Library and Collection and Harvard University Press, 2005. Rodley says that about Selime site that "its elements and their arrangement conform to the basic pattern seen in other complexes", Cave Monasteries, p. 141.
} 
stables, pigeon houses, wine presses, hideouts for situations when refuge was necessary, and cemeteries. (As we shall see, most of these are elements common to an aristocratic oikoi, a monastic community, a village, and a town). Çanlı Kilise's large precinct contains, among others, the church with a bell ('bell' is the meaning of the word çan); this is a constructed (masonry) building and was erected either in the eleventh or thirteenth centuries. ${ }^{16}$ The smaller complex around St. Stephen's Church, close to Cemil in Ürgüp area, has similar elements to the above (fig. 2). ${ }^{17}$ The controversies regarding the foundation of the church at the latter site and its painted decoration placed it within a temporary span of four centuries: between the seventh and the eleventh. ${ }^{18}$
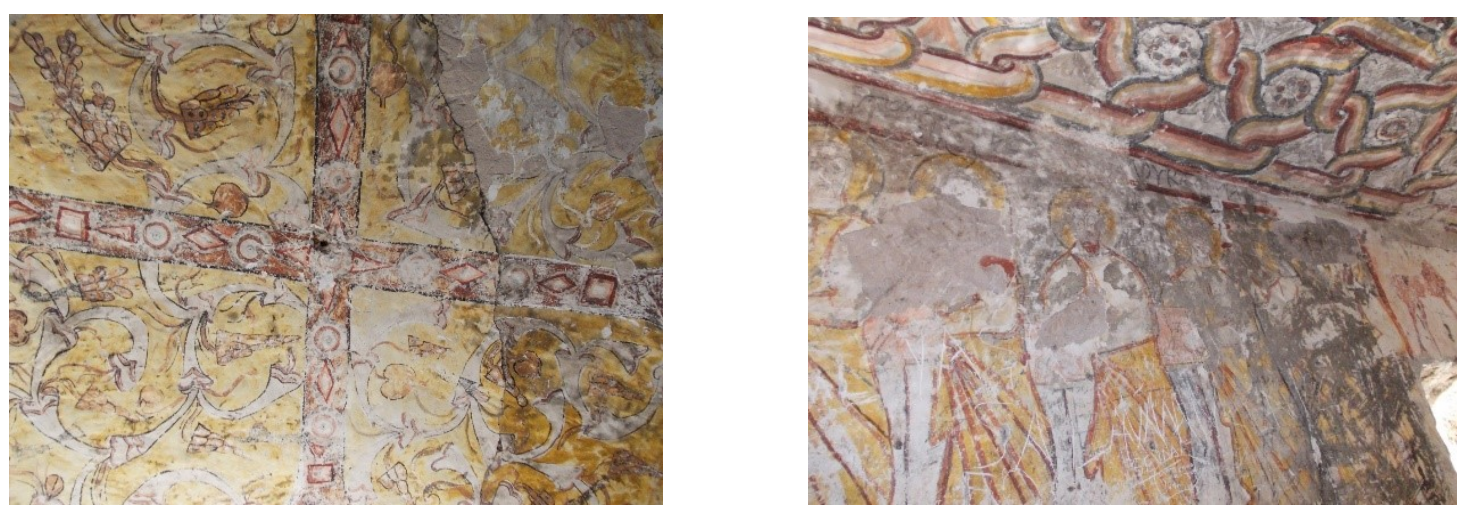

Fig. 3 a, b: a) St. Stephen's Church. Decoration on the celling of the nave; b) St. Stephen's Church. Decoration on a wall and the celling of the nave. I personally believe that the first layer of painting - that which covers the most of the ceiling of the church - is from the seventh or even sixth century; photos E.E D-V taken in May 2015.

Generally speaking, all the sources referring to a medieval Byzantine oikos (a household with all its annexes) - and that includes references to Cappadocia during the Empire - testifies that it consisted of vineyards, land planted with vegetables, parks, at least a church, houses which sometimes had separate apartments (koitônes), a hall, and various other annexes. ${ }^{19}$ In

\footnotetext{
${ }^{16}$ Ousterhout, A Byzantine Settlement in Cappadocia, p. 172 (he opts for the tenth-eleventh centuries - the Middle Byzantine period); C. Jolivet-Lévy, Les églises byzantines de Cappadoce, p. 287.

${ }^{17}$ Ousterhout, Visualizing Community, pp. 202, 206; C. Jolivet-Lévy, Les églises byzantines de Cappadoce, pp. 161-163.

18 Jolivet-Lévy, Les églises byzantines de Cappadoce, p. 163.

19 Paul Magdalino, "The Byzantine Aristocratic Oikos", in M. Angold (ed.), The Byzantine Aristocracy lX to Xlll Centuries, Oxford: B.A.R9 International Series 221, 1984, pp. 92-93, 95 [pp. 92-112]. For various aspects of oikos and Byzantine economy in general see Angeliki E. Laiou (editor-in-chief), Charalambos Bouras, et al., The Economic History of Byzantium: from the seventh through the fifteenth century, Dumbarton Oaks Studies 46, Washington D.C.: Dumbarton Oaks Research Library and Collection and Harvard University Press,
} 
some cases, a 'wardrobe' (vestiarion) existed, and also "an outdoor dais (souphas) or a 'little building' (oikistos) to house a study-cum-library." ${ }^{20}$ Among the concrete examples of Byzantine structures comprising some of those elements are the early tenth-century palace Myrelaion in Constantinople (which has similarities especially with Çanlı Kilise ${ }^{21}$ ) and the "House of Botaneiates" (the Constantinopolitan palace given by Isaac 11 to the Genoese). ${ }^{22}$ To those we might add the "more ambitious non-imperial lay residence[s]" mentioned by Paul Magdalino: the palace belonging to Theodore Metochites in Constantinople that is verbally portrayed as consisting of "a complex of buildings grouped around a central courtyard with a church in the middle." ${ }^{23}$ The neos oikos created by Basil I (reigned in 867-886) and the oikos at Mangana, to which Constantine IX Monomachos (reigned in 1042-1055) added that of St. George the Tropaiophoros was, according to Nikolaos Oikonomides, a palace with wonderful gardens, a monastery with the church dedicated to the afore-mentioned saint, a charitable institution, and a law school; ${ }^{24}$ the latter was the extension of the university founded in 425 by Emperor Julian, and which Constantine IX Monomachos re-established in 1054.

\footnotetext{
Dumbarton Oaks Studies 39, 2002; Marlia Mundell Mango, "The Commercial Map of Constantinople", Dumbarton Oaks Papers, 54, 2000, pp. 189-207; George C. Maniatis, "The Domain of Private Guilds in the Byzantine Economy, Tenth to Fifteenth Centuries", Dumbarton Oaks Papers, 55, 2001, pp. 339-369; Johannes Koder (ed. and trans), Das Eparchenbuch Leons des Weisen, Verlag der Österreichischen Akademie der Wissenschaften, Vienna, 1991; the latter writing was edited and trans. by Jules Nicole as Le Livre du Préfet ou l'édit de l'empereur Léon le Sage sur les corporations de Constantinople, Geneva and Bale: Georg\&C ${ }^{\circ}, 1894, \mathrm{I}$, 20 (the trilingual edition based on Genevensis Graecus 23). Its details in English are thus: To eparchikon vivlion/Livre du préfet/The book of the Eparch, Jules Nicole, Edwin Hanson Freshfield, and Ivan Duǐchev (eds.), London: Variorum Reprints, 1970 (E. H. Freshfield was also the translator and the editor when he published this 'report' in Roman Law in the Later Roman Empire, 1938). Commentaries and references about The book of the Eparch are, for instance, in Alexander Kazhdan (ed.), Oxford Dictionary of Byzantium, New York and Oxford: Oxford University Press, 1991, vol. 1, and M.F. Hendy, "Light Weight Solidi, Tetartera and the Book of the Prefect", Byzantinische Zeitschrift 65 (1972), pp. 57-80.

${ }^{20}$ P. Magdalino, "The Byzantine Aristocratic Oikos", p. 95.

${ }^{21}$ Ousterhout, A Byzantine Settlement in Cappadocia, p. 142.

${ }^{22}$ Magdalino, "The Byzantine Aristocratic Oikos", p. 95.

${ }^{23}$ Idem, p. 96.

${ }^{24}$ We know these, for instance, from Michael Psellos, Chronographie ou Histoire d'un siècle de Byzance (9761077), trans. Emile Renauld, Paris: Les Belles-Lettres, 1928, I, 143-144; II 61-63; Michael Attaliotes, Historia, ed. by Immanuel Bekker and Charles M Brunet de Presle, Bonn: Weber, 1853, 71; John Skylitzes, Synopsis historiarum, ed. by Hans Thurn, Berlin-New York: De Gruyter, CFHB 5, 1973, 476-477 (trans. by J. Wortley as A Synopsis of Byzantine History, 2010), and John Zonaras, Epitomae historiarum, edited by T. Biittner-Wobst, Bonn: CSHB, 1897, III, 619-20, 646, 647 (in English, The History of Zonaras from Alexander Severus to the Death of Theodosius the Great, edited and trans. by Thomas Banchich and Eugene Lane, London: Routledge
} 
Typical in the countryside was a 'manor house' ("the nucleus of every oikoproasteion"25). But, as we know from the inventory of the domain at Baris given to Andronikos Doukas in 1073, this had a similar configuration to that of the above-mentioned households: a domed church, an arched cruciform hall (triklinos) with four chambers (kouboukleia), and a bath; ${ }^{26}$ some of the residences consisted in "multi-storey houses." 27 Perhaps it is useful to emphasize with Magdalino that "the difference between the smallest 'manor-house' and the largest urban palaces was one of degree, not of kind," 28 and that "the monastery was in more ways than one the alter ego of the secular oikos [...] far from being a negation of the extended household." ${ }^{29}$ He supports the opinion communicated via the latter sentence through Symeon the Theologian's statements that households had similarities regardless if they belong to "an aristocrat (archontikos) or pious (euagēs) oikos or a monastery", and that "not houses, not baths, not villages or vineyards and estates" distinguish lavrai and monasteries from the worldly because they also contain all of these. ${ }^{30}$ Magdalino further adds that "Episcopal and monastic establishments resembled those of lay magnates not only in that the bishop's household and the cenobitc monastery formed the hub of a large complex of diverse and scattered sources of landed wealth, but also in that architecturally and functionally they had much in common." 31

2009). See also Nikolaos Oikonomides, "St. George of Mangana, Maria Skleraina, and the 'Malyj Sion' of Novgorod", Dumbarton Oaks Papers 34-35 (1980-1), p. 241 [pp. 239-246].

${ }^{25}$ Magdalino, "The Byzantine Aristocratic Oikos", p. 95.

${ }^{26}$ Ibid.

${ }^{27}$ Magdalino, "The Byzantine Aristocratic Oikos", p. 96.

${ }^{28}$ Idem, p. 95.

${ }^{29}$ Idem, p. 102.

${ }^{30}$ Symeon the New Theologian, "Catachèses", edited by Basil Krivocheine, Sources Chrétiennes, Paris: Les Éditions du Cerf, 1965, vol. 1, p. 440.

${ }^{31}$ Magdalino, "The Byzantine Aristocratic Oikos", p. 94. 


\section{i. 1. The roles fulfilled by churches in Cappadocia from the fifth to the eleventh century}

We shall now indicate the ways in which, in addition to being the spaces where the Liturgy was celebrated, the churches in Cappadocia served communities as those described above. One function they fulfilled was to be the means through which the patrons expressed their piety and the hope of forgiveness of their sins. The founders did that not only by establishing the churches themselves (adapting the caves and constructing some of masonry), but also by commissioning inscriptions and images, and making various donations (books, vestments, furniture, land, etc.). Concerning the inscriptions, a well-preserved one exists in Göreme church 21 that is dedicated to St. Catherine, where the woman Anna addresses directly the saint; similar texts are to be found in the hermitage of Niketas - an invocation to Theotokos is here $^{32}$-, and also in St. Eustathios church. ${ }^{33}$

With regard to the patronage of works of iconography, we should remind the readers again that this part of Anatolia "was an important province of the Byzantine Empire" and "a vibrant area of habitation, with hundreds of settlements, churches, and monasteries carved into the rocky landscape. More than seven hundreds alone have been counted in the region, many of them preserving impressive ensembles of fresco decoration." ${ }^{34}$ It is important to mention the presence of the Byzantines from Phocas family in Cappadocia during the tenth and eleventh century and the foundations carried out and embellished by them. Two inscriptions in the New Tokalı Church/ Tokalı Kilise in Göreme (fig. 4), painted in the middle of the tenth century, indicate that it was decorated by "Constantine, Nicephore and Leon, sons of Constantine". ${ }^{35}$

\footnotetext{
32 Ousterhout, Visualizing Community, p. 406.

${ }^{33}$ Idem, p. 480.

${ }^{34}$ Ousterhout, A Byzantine Settlement in Cappadocia, 'Introduction to the first edition", p. 3.

35 Jolivet-Lévy, Les églises byzantines de Cappadoce, p. 108. She points out that it is very difficult to establish when the New Tokalı Church was founded, but considers the paining as belonging to mid tenth century (950960); she indicates that she shares with N. Thierry in this (footnote 201 on page 108). Ousterhout, in Visualizing Community has a very large section dedicated to Göreme, but does not have any attempt to date this particular church. He considers some structures there as beings creations of the eleventh century ("and perhaps" of the early twelfth).
} 


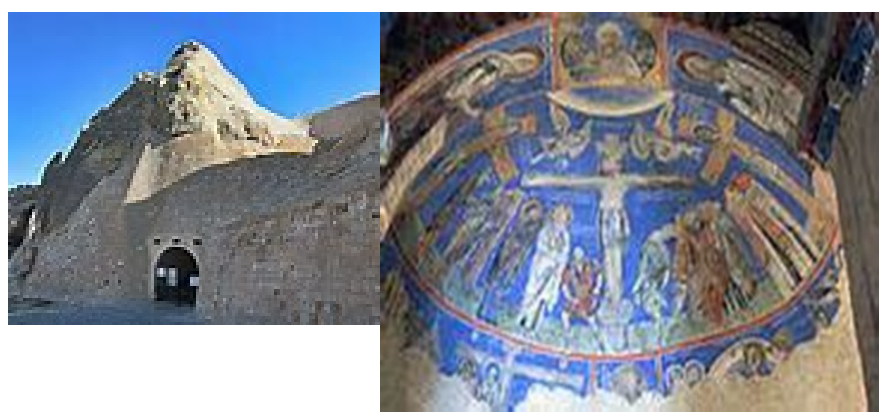

Fig. 4. The new Tokali Kilise/Church, Göreme; the access to these images is licensed under the Creative Commons Attribution 2.0 Generic.

The fresco-painters signed their works in spite of the fact that canonically they were not supposed to do so. [This is not the only instance where the rules were not strictly observed; in general, an iconographer was known through his work, ${ }^{36}$ so the churches themselves made this type of creator known].

The written dedications in the above-mentioned New Tokalı Church are situated thus: one on the cornice of the nave and the other in the north apse. The family name of the patron is not mentioned, but since that was rather the norm in Byzantium and, as Catherine Jolivet-Lévy reveals, the three names of the funders are - with Bardas - well attested in the family of Phocas, it is very likely that this church is their creation, and that they extended the building of the Old Tokalı (or, as Nicole Thierry calls it, Tokalı 1; she speaks about these two connected foundations in terms of Tokalı 1 and Tokal1 2). It has been scholarly acknowledged that the same epigraphic sources testify that this 'new' church at Göreme belonged to a monastery dedicated to the Archangels. The quality of the painting within, the use of lapis lazuli and of gold and silver for a few of the haloes point out to rich patrons, and the Phocas were so. Jolivet-Lévy thinks that the iconographers might have been brought from Constantinople. She suggests that it was Constantine, one of the three sons of Bardas Phocas, who initiated the building of this church. He was taken prisoner in 953 and died in Aleppo. It is very probable that Leon and Nicephoros continued his work; they might have been his sons, as the inscriptions seem to imply, but it is also possible that they were his brothers. It is known that

\footnotetext{
${ }^{36}$ Before the twentieth century icon and fresco painters were only men.
} 
Nicephoros II Phokas (Byzantine Emperor in 963-969) was born in Cappadocia in 912, and that he was appointed the sebastokrator of the Anatolikon Theme in 945 under Constantine VII Porphyrogenetus (reigned in 913-959). He was proclaimed emperor by his troops in Caesarea, and crowned in Constantinople. ${ }^{37}$ Even though, as Jolivet-Lévy argues, it is true that the imperial title is absent from the dedication in the New Tokal1, that should not prevent him being considered the continuator of his brother's efforts (only in 963 was Nicephoros declared emperor and went to the capital; therefore he could have become involved in the foundation of the new church long before that moment). ${ }^{38}$ Nicephoros as an Emperor is represented in the northern apse of the Pigeon House (Dovecote) at Çavuşın with his wife Theophano (on his left), and his father and one of his brothers (on his right). That proves that he was popular in the area -and not only for his military achievements, but also for his patronal endeavours. In addition to the inscriptions and images at Tokalı and Çavuşın, we can also mention the Byzantine church St. Barbara (today also known as Tahtala) in Soğanlı Valley, which Kalas considers in her article "Early Explorations of Cappadocia and the Monastic Myth". The researcher specifies that the dedicatory inscription there refers to emperors Basil II (976-1025) and Constantine VII Porphyrogenetus and, as far as lettering allows a reasonable reading, it is dated either to 1006 or $1021 .{ }^{39}$ The existence of cave-churches and buildings bearing traces of inhabitancy as well as that of the paleographic and iconographic elements as those mentioned here - all reflecting aspects of the ethos of the Empire - enticed the attention of a few researchers as early as the nineteenth century and have retained the interest of contemporary scholars. In consequence of surveying the literature in the field, Kalas concludes with good reason that "In many ways, Cappadocia is one of the birthplaces of the modern study of

\footnotetext{
${ }^{37}$ Gilbert Dragon and Haralambie Mihăescu, Le traité sur la guérilla (De velitatione) de l'empereur Nicéphore Phocas, Paris: Broché 1986, reprint 2011.

${ }^{38}$ Catherine Jolivet-Lévy and Claude Sauvageot, "La Cappadoce médiévale: images et spiritualité [Saint-LégerVauban]: Zodiaque, 2001, pp. 58-67. See also Paul M. Schwartzbaum, Tokalı Kilise: Tenth-century Metropolitan Art in Byzantine Cappadocia, 1986.

${ }^{39}$ Veronica G. Kalas "Early Explorations of Cappadocia and the Monastic Myth", in Byzantine and Modern Greek Studies 28, 2004, p. 110.
} 
Byzantine architecture". ${ }^{40}$ With respect to the lack of decoration peculiar to some churches in the area, she underlines that their aniconicity does not necessarily mean that they were built before the iconoclastic controversy. ${ }^{41}$ In saying this she dialogues with N. Thierry, who usually places the construction of these shrines in the historical period when iconodoules and iconoclasts debated. ${ }^{42}$ As a part of the discussion about the unornamented churches, Ousterhout comments that Thierry "likes" to place in the pre-iconoclastic era those with "nonfigural painted or carved decoration" although "none is securely dated". ${ }^{43}$

Among the decorated churches of which embellishment would have attracted people and brought recognition to the fresco-painters, worth mentioning is that of Kızıl Çukur in Çavuşin region, founded in the sixth-seventh century (there is still a controversy about this dating). ${ }^{44}$ The monument contains a depiction of the Mariological cycle in its northern chapel, which is dedicated to Anne and Joachim. Ten scenes from the initial twelve have survived (among them, that which contains the famous representation of Anna pregnant). N. Thierry and many other researchers as Jacqueline Lafontaine-Dosogne, ${ }^{45}$ Paul A. Underwood, ${ }^{46}$ Ann Wharton-Epstein, ${ }^{47}$ and Adriana Balaban Bara ${ }^{48}$ highlight that the usual episodes of such a

\footnotetext{
${ }^{40}$ V. G. Kalas, "Early Explorations", p. 107.

${ }^{41}$ Idem, pp. 112-114.

${ }^{42}$ N. Thierry, "Mentalite et Formulation", pp. 81-119.

${ }^{43}$ Ousterhout, Visualising, p. 14.

${ }^{44}$ Nicole Thierry proposes these dates in 1998 and maintains them in 2002; N. Thierry, La Cappadoce de l'antiquité au Moyen Âge, Brepols, Turnhout (Bibliothèque de l'Antiquité tardive 4), 2002, pp. 122-123. This text was initially published as "La Cappadoce de l'antiquité au moyen âge," Melanges de l'Ecole francaise de Rome. Moyen Age, vol. 110, no. 2 (1998), pp. 867-897; the dating of Klzll Çukur is on p. 888. See also N. Thierry, Çavuşin, Geuthner Paris, 1994, vol. 2, p. 228. Such a proposal improves on that about the church's establishment in the tenth-eleventh centuries offered by André N. Grabar and other researchers. See A. N. Grabar, Christian iconography: a study of its origins, Routledge and Kegan Paul, London, 1969, p. 129, and also Ann Wharton-Epstein, "Rock-cut chapels in Göreme Valley, Cappadocia: the Yilanli group and the column churches," Cahiers archéologiques. Fin de l'antiquité et moyen-âge, vol. 24 (1975) [pp. 115-135], p. 118.

${ }^{45}$ Jacqueline Lafontaine-Dosogne, Iconographie de l'enfance de la Vierge dans l'empire byzantin et en Occident, Brussels, 1964, vol. 1, pp. 62-65.

${ }^{46}$ Paul A. Underwood, The Kariye Djami, Bollingen Series LXX, Pantheon Books, New York, 1966, vols. 1-2. Vol. 1 is entitled "Historical Introduction and Description of the Mosaics and Frescoes") and vol. 2, which contains 'Plates 1-334', is entitled as such.

${ }^{47}$ Ann Wharton-Epstein, "Rock-cut chapels in Göreme Valley, Cappadocia: the Yilanli group and the column churches," Cahiers archéologiques. Fin de l'antiquité et moyen-âge, vol. 24 (1975) [pp. 115-135], p. 118.

${ }^{48}$ Adriana Balaban Bara, The Political and Artistic Program of Prince Petru Rareş of Moldavia; doctoral dissertation, University of Montreal, 2012.
} 
cycle are Joachim's Offerings Rejected, Joachim and Anne Returning Home [sometimes artists conflate these two]; Saint Joachim in the Wilderness, Nativity of the Virgin); the Virgin Blessed by the Priests, Mary's first steps ${ }^{49}$, and the Presentation of the Virgin to the Temple. Sometimes the scene of the breastfeeding of Mary by Anne is included within the series. An interesting fact is to be noted with respect to the embellishment of the chapel in Kizıl Çukur: the face of the servant in the Mariological cycle is similar to that of Mary in Santa Maria Nuova church, Rome (sixth-eight centuries; fig. 5); such a reality confirms the current dating of the Cappadocian site. ${ }^{50}$

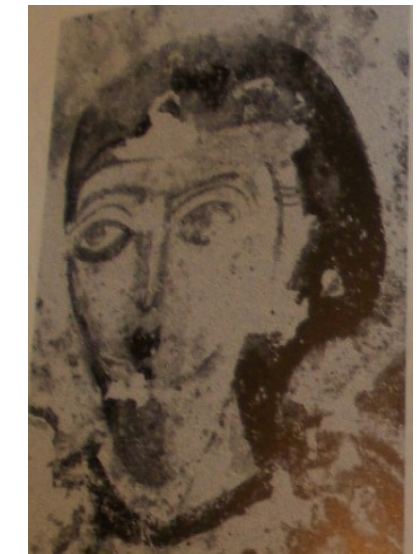

a)

Fig. 5. a). The face of a servant in the chapel of Joachim and Anna, Cappadocia; N. Thierry, La Cappadoce de l'antiquité au Moyen Âge, a part of fig. 89 on p. 131 (Thierry follows A. Grabar on this particular iconographic detail); fig. b) The icon representing Mary and child in Santa Maria Nuova (today Santa Francesca Romana); this is in the public domain via http://worldimages.sjsu.edu/media/images/byz04_byzantine/byz04029.jpg.

Thierry emphasizes that some of the paintings in the chapel reflect the Christological debate of the seventh century: they allude to the compromise reached by Emperor Heraclius (610 - 641) and the Church to alleviate the disagreements among the religious groups peculiar to that time. Also the above enumerated Mariological depictions at Kizıl Çukur express theological notions.

\footnotetext{
${ }^{49} \mathrm{P}$. A. Underwood discusses and reproduces the fourteenth century mosaic at Chora, which represents this scene according to the imagination of the fresco-painters; P. A. Underwood, The Kariye Djami, vol. 1 pp. 60-72, vol. 2, pp. 86-124.

${ }^{50}$ N. Thierry, La Cappadoce de l'antiquité au Moyen Âge, fig. 8 on p. 131.
} 
The French scholar comments on their representation in this church: "The thirteen scenes of the story [about Mary's life] are exceptionally complemented by a Virgin in the mandorla painted on the eastern tympanum, flanked by two inclined angels (pl. 37, fig. 88). Glory is an Old Testament attribute of the Divinity (Ezek. 1, 28; 43, 4) and the extent to which it applies to the Mother of God is still being discussed". 51

The mosaic in the apse of the Cypriot church of Panagia Kanakaria Lythrankomi that visually narrates the Christological cycle is also worthy of mention. This is considered by Marina Sacopoulo to be "an attempt to illustrate the two natures of Christ, who 'inserted' divinity into humanity and is supposed to constitute the Orthodox response to the Monophysites". ${ }^{52}$ Dimitri Obolesky, ${ }^{53}$ Melina Paisidou, ${ }^{54}$ and Saska Bogevska-Capuano ${ }^{55}$ speak about an ideatictheological-iconographic parallelism. Bogevska-Capuano points out a rendering of Trinity in Omorphokklesia church near Kastoria (thirteenth century) as a tricephalous man, an iconographic motif she sees as being one of the elements that constitutes the mark of Western influence on Byzantine iconography. I personally consider its rendering to be an experiment.

\footnotetext{
51 "Les treize scènes du récit sont complétes par une exceptionnelle Vierge dans la mandorle peinte sur le tympan oriental, encadrée par deux anges inclinés (PL. 37, fig. 88). La gloire est un atribut vétérotestamentaire de la divinité (Éz. 1, 28; 43,4) et son extension a la Mère de Dieu prête à discussion. On ne connaît qu'un autre exemple, la mosaïque chypriote de l'abside de la Panaghia Kanakaria de Lythrankomi attribuée au vie de Sauveur celle-ci est considérée comme un tentative illustration des deux natures du Christ, ce serait l'Humanité insérée dans la Divinité, une response orthodoxe aux Monophysites." N. Thierry, La Cappadoce de l'antiquite, au Moyen Âge (Bibliothèque de l'Antiquité tardive 4), Brepols, Turnhout, 2002, p. 123; my translation.

${ }_{52}$ Marina Sacopoulo, La Théotokos à la mandorle, Paris, 1975, pp. 70-87; N. T. HMÂC, II, pp. 214, 235-236. See also Ernest J. W. Hawkins, The Church of the Panagia Kanakariá at Lythrankomi in Cyprus. Its mosaics and frescoes, Washington D.C.: Dumbarton Oaks Research Library and Collection and Harvard University Press, Dumbarton Oaks Studies, 1977.

${ }^{53}$ Dimitri Obolesky in The Bogomils: A Study in Balkan Neo-Manichaeism, Cambridge University Press, Cambridge, 1948, reprint AMS Press, New York, 1978, presents Zygabenus's description of the notion of Trinity as he thought the Bogomils saw it, pp. 211-212. The Russian-British author identifies two concepts ("or rather two separate aspects" of one) in the works of the Byzantine monk commissioned to report on them. The one presented above (Father, Son, and the Satanael) was well described by Michael Psellus in Dialogus de daemonum operatione. The second Trinity in Bogomil understanding consists in the Father, Son and the Holy Spirit. The representatives of the South-European sect under discussion here take the Son and the Holy Spirit to be names or emanations of the Father "[like] two rays proceeding from the two lobes of his brain". This kind of representation does not exist in any other source except Zygabenus's writings.

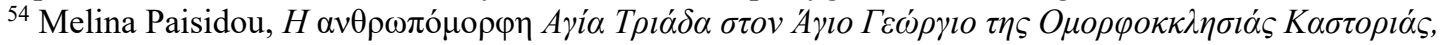

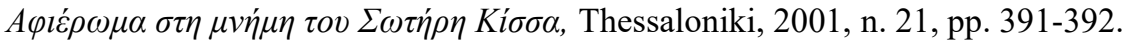

${ }^{55}$ Saska Bogevska-Capuano, "The Holy Trinity in the Diocese of the Archbishopric of Ohrid", pp. 150-151, figs. 9-10. Her comments on the Bogomils are on pp. 155-156.
} 
Hagiography was also employed to mirror contemporary theological debates. The best known example from this point is the iconographical scene 'Paul and Peter embracing' that occurred during the preparations for the Council of Ferrara (more precisely, Basel-Ferrara-Florence), which tried a rapprochement between Eastern and Western Christianity in 1431-1449. ${ }^{56}$ Debates have also taken place in scholarship as to whether the decorations in Saint Appolinare Nuovo, Ravenna reflect Arian or Nestorian ideas. ${ }^{57}$

It should be underlined that a large array of iconographic themes exists in Cappadocian churches. As stated throughout the paper, the dating of certain frescoes that represent these have been controversial; the exemplars I have seen left me with the strong impression that some of them were executed before any iconographic typicon or Hermeneia reached the area. In some early buildings one finds the entire cycle of the Life of Jesus and/or of Mary painted in continuous uninterrupted registers, with no concern for where the scenes best serve the needs of the believer. Moreover, some of the episodes shown were based on apocryphal sources or oral tradition (as opposed to the Bible itself). This is the case, for instance, with the scene 'Crucifixion' in Kokar Church (dated, depending on the source, to between the second half of the ninth century and the second half of the eleventh ${ }^{58}$ ) in which Jesus is represented clothed (fig. 6).

\footnotetext{
${ }^{56}$ Maria Vassilaki, "Painting Icons in Venetian Crete at the Time of the Council of Ferrara-Florence (1438/1439)", paper presented at the conference Icons and Iconology, Rijeka, 1-4 June, 2015; published in the journal IKON 9 (2015), pp. 41-53.

${ }^{57}$ Arthur Urbino, "Donation, Dedication, and Damnatio Memoriae: The Catholic Reconciliation of Ravenna and the Church of Saint's Apollinare Nuovo", JECS 13, 2005, p. 88 [pp. 71-110]; R. M. Jensen, "The Economy of the Trinity at the Creation of Adam and Eve", JECS 7, 1991, p. 528 [pp. 527-546].

${ }^{58}$ Jolivet-Lévy, Les églises byzantines de Cappadoce, p. 303.
} 


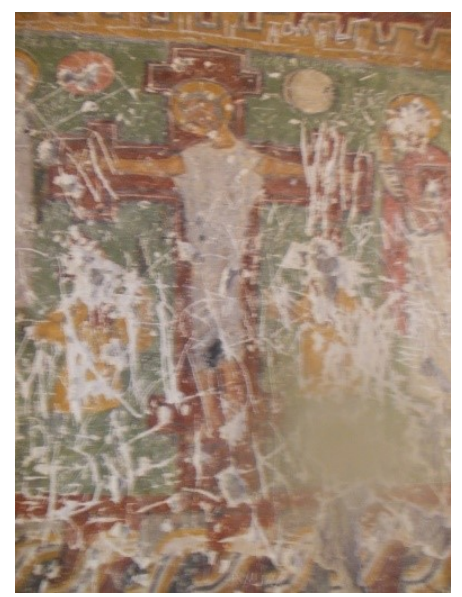

Fig. 6. In Kokar Church there are two 'Crucifixion' scenes along one another - in one of them Christ is clothed on the Cross; frescoe dating to the period between the second half of the ninth century and the second half of the eleventh century; ${ }^{59}$ photo E.E D-V taken in May 2015.

Another instance is a particular fresco rendering the 'Flight to Egypt' in the Old Tokall church, Göreme ${ }^{60}$ that depicts a young man leading the donkey on which Mary travels (fig. 7); a similar scene exists in Pürenlı Seki of which decoration had been attributed to the first half of the tenth century, ${ }^{61}$ fig. 8).

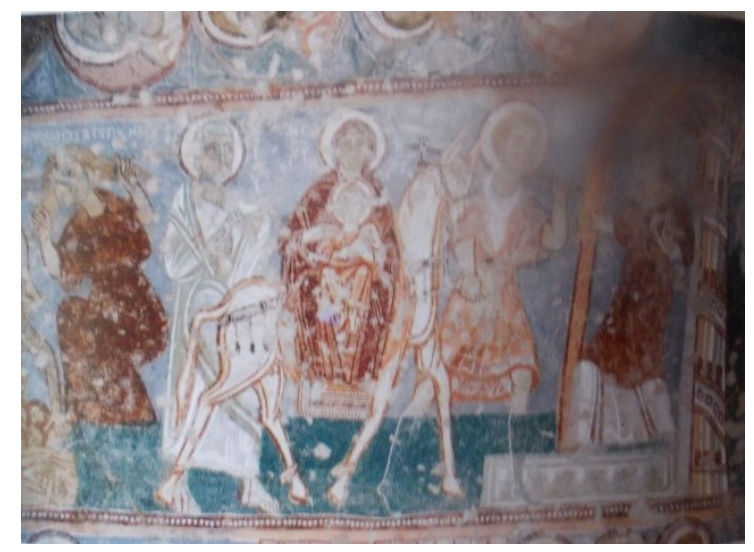

Fig. 7. Old Tokall church in Göreme; tenth century. Mary, the child Jesus, and Joseph on the Flight to Egypt. As in the scene below, the donkey is led by James, Christ's half-bother; photo E.E D-V taken in May 2015.

\footnotetext{
59 Jolivet-Lévy, Les églises byzantines de Cappadoce, p. 303.

${ }^{60}$ Jolivet-Lévy, Les églises byzantines de Cappadoce, p. 96; she specifies that the frescoes were accomplished by Saint-John de Güllü dere in 913-920. She adds that those in the north-east niche are "probably anterior to those".

${ }^{61}$ Jolivet-Lévy, Les églises byzantines de Cappadoce, p. 305; she makes a note with respect to the controversies surrounding such a dating.
} 


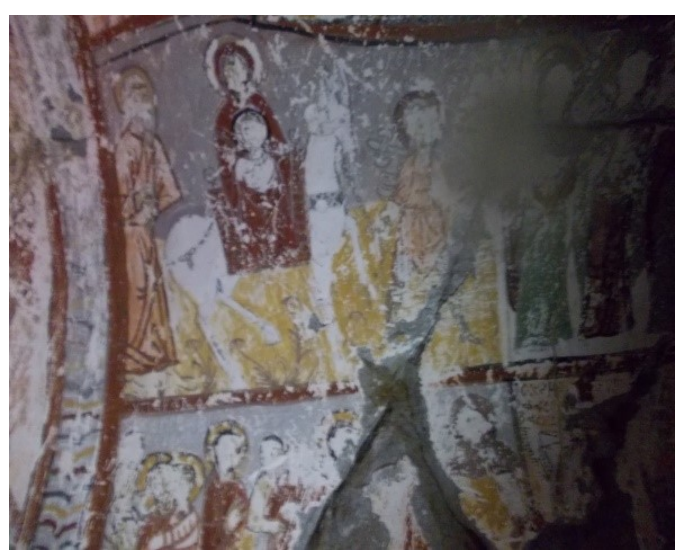

Fig. 8. Pürenli Seki Church. The Flight to Egypt. In the same manner as above, the donkey is led by James, Christ's half-bother. Fresco dating to the period between the second half of the ninth century and the second half of the eleventh century; ${ }^{62}$ photo E.E D-V taken in May 2015.

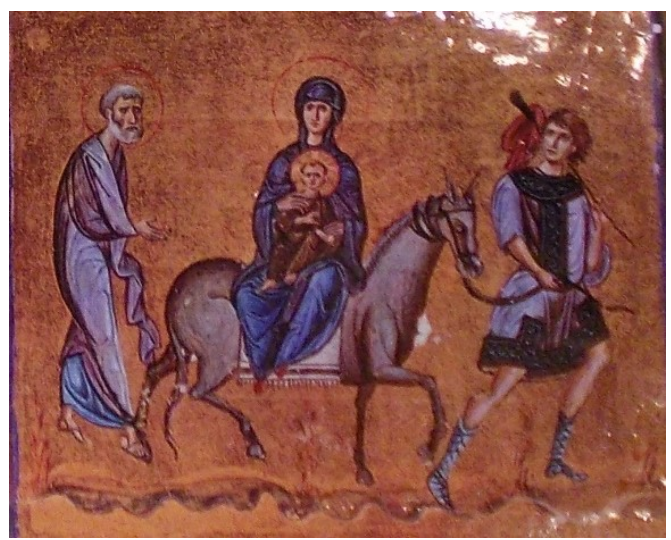

Fig. 9. Image from ms. Cod. 587 [a Gospel lectionary], Monastery of Dionysiou; fol. 133v, eleventh century. The Flight to Egypt. James, Jesus's brother, leads the donkey. The image is reproduced in The Treasures of Mount Athos, ed. S. M. Pelekanides et al., trans. Philip Sherrard, Ekdotike, Athenon, vol. 1, 'Illuminated Manuscripts', p. 200

According to both written sources and local tradition, the donkey is guided by James, Christ's half-bother; he is mentioned within the Bible at Gal. 1:19. A similar image - in which the animal is led by a young man - appears in the representation of 'The Flight to Egypt' within ms. Cod. 587 [a Gospel lectionary] from the Monastery of Dionysiou, fig. 9). ${ }^{63}$ An unusual

\footnotetext{
${ }^{62}$ Jolivet-Lévy, Les églises byzantines de Cappadoce, p. 303.

${ }^{63}$ Ms. Cod. 587 [a Gospel lectionary] from the Monastery of Dionysiou, fol. 133v; eleventh century. The image is reproduced in The Treasures of Mount Athos, ed. S. M. Pelekanides et al., trans. Philip Sherrard, Ekdotike Athenon, vol. 1, Illuminated Manuscripts, p. 200, bibliography on page 435. Various local notices, brochures, and volume exists in Cappadocia, many written by local specialists. While unable to verify in all cases how accurate they are, in terms of dating the local churches their estimations coincide with those of Western scholars who studied there. Their ideas coincide also from other points of view. In this context I can mention that Murat E. Gülyaz, writes in a book entitled Cappadocia. Nature. History. Culture, Retma Publishing House, 2006, no location, that the third person in the Flight to Egypt scene in Old Tokal1 is a 'manservant', p. 48. (On p. 60 Gülyaz introduces himself as an Archaeologist.)
} 
iconographical motif present in Cappadocia - for instance in Kılıçlar church (mid tenth century $)^{64}$ and in the Old Tokal1 - is the trial of Mary and Joseph for scandalous conduct.

During the hearing they were tested by being summoned to drink the water of reproach [according to Numbers 5. 16-17; 24-26; 28-31 ${ }^{65}$ ].

Hagiography is well represented in churches founded during the Byzantine period of Cappadocia. For instance, Gregory of Nyssa is depicted full-length in a fresco at Y1lanlı Kilise, fig. 10. He is represented next to the Virgin and among other religious figures. It is probable that this church was dedicated to St. Mary because her image has a significant place within the building. The decoration of this edifice has been dated to the tenth century ${ }^{66}$ and it is to be assumed that the particular mural described here belongs to the same period,

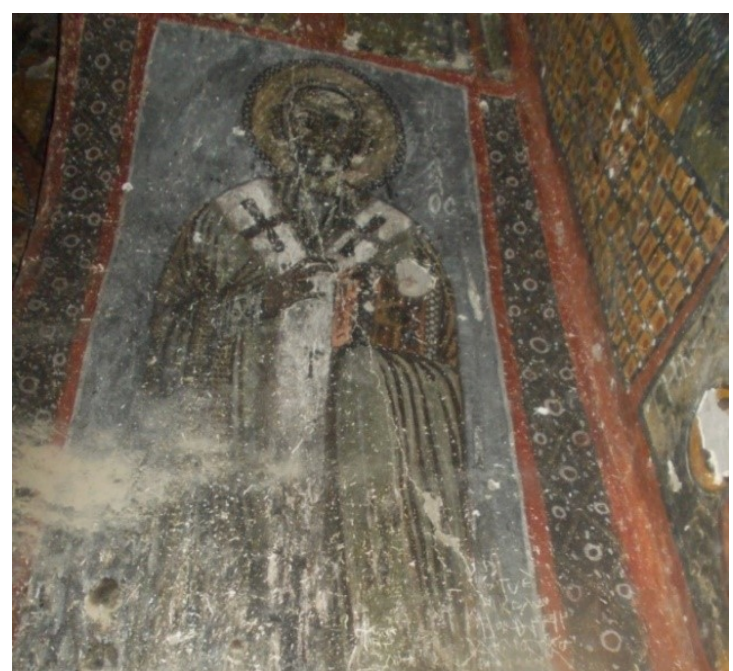

Fig. 10. Yılanlı Kilise, St. Gregory of Nyssa; fresco from the tenth century; photo by E.E D-V taken in May 2015.

The other illustration referring to saints is from the church of St. Theodore. ${ }^{67}$ Here Basil of Caesarea, Gregory of Nyssa, and Gregory Nazianzen are represented, and the rarely painted Eustache of Sebasta/Sebasteia also appears; fig. 11.

\footnotetext{
${ }^{64}$ Judith A. Cave, The Byzanting Wall Paintings of Kiliçlar kilise: Aspects of Monumental Decoration in Cappadocia, Ph. D. Diss., Pennsylvania State University, 1984.

${ }^{65}$ The Holy Bible, King James Version, Nelson Bibles, pp. 125-126. Elizabeth Jeffreys mentioned this scene in her paper entitled "The Homilies of James of Kokkinobaphos in their twelfth-century context", delivered at the seventeenth International Conference of Patristic Studies, Oxford.

${ }^{66}$ Jolivet-Lévy, Les églises byzantines de Cappadoce, p. 311.

${ }^{67}$ About St. Theodore church see, for example, Ousterhout, Visualizing Community, p. 111.
} 

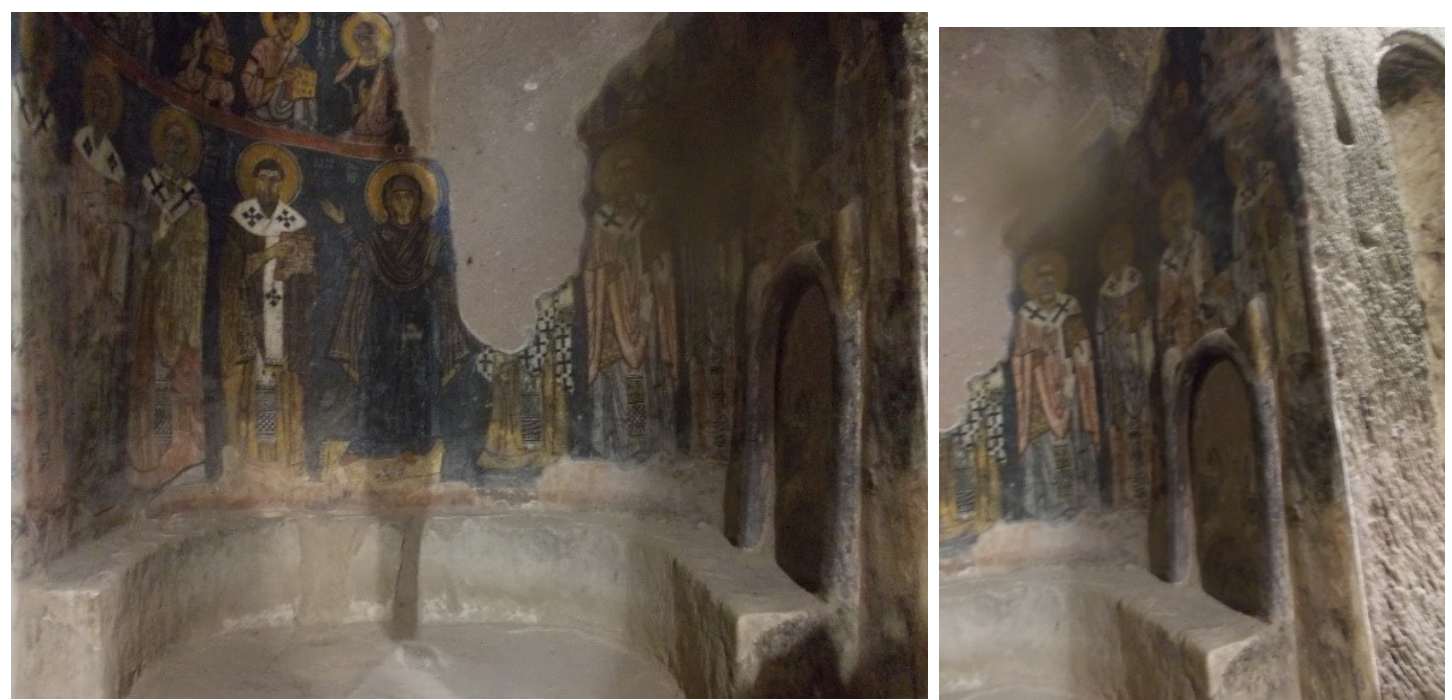

Fig. 11. The Theotokos and the Cappadocian Fathers, including St. Eustache of Sebasta/Sebasteia in the church of St. Theodore in Yeşilöz, eleventh-thirteenth centuries; photos E.E D-V taken in May 2015.

As suggested earlier, the churches in Cappadocia also served the spiritual necessities of army garrisons. The reality that a military presence was a fundamental part of the landscape is obvious from the fact that many settlements were strategically placed and also that some were fortified in a manner that reveals martial expertise (we have seen this with respect to Selime). Also paleography and iconography provide evidence that testifies to the presence of soldiers and of their religious needs. In this context, James Crow's study concerning the distribution of inscriptions referring to garrisons along the borders is to be remarked upon; most of those are in Greek. ${ }^{68}$

In terms of iconography, the depiction of military saints in various churches throughout Cappadocia (for instance, in St. George Church, Göreme site) could be an indication that either the patrons or the attendants had connections with the army or were soldiers. Fatma Gül Öztürk considers that some of the architectural structures in Cappadocia were "mansions

\footnotetext{
${ }^{68}$ See James Crow's entry '1245. Cappadocia - the Eastern frontier' that mentions "our lemma no. 1566"; Supplementum Epigraphicum Graecum, Leiden, Boston: Brill, vol. XXXV1, 1986, p. 382. See also Andreas Rhoby's work Inscriptions in Byzantium and beyond: methods - projects - case studies, the 22nd International Congress of Byzantine Studies (Sofia, Bulgaria), Vienna: Verlag der Österreichischen Akademie der Wissenschaften, OAW, 2015.
} 
of the landowning elites with military associations who dominated the region during the $10^{\text {th }}$ and $11^{\text {th }}$ centuries." $" 69$

In addition to the main shrines about which we have spoken above, a multitude of smaller churches existed in various settlements. They would have also welcomed not only local believers, but others coming from the nearby towns and villages, as well as the various categories of people already mentioned in the case of sizeable churches. Even, for instance, small hermitages such as those dedicated to Niketas in the Kizil Çukur (late ninth century ${ }^{70}$ ) and to St. Symeon in Çavuşın (eleventh century ${ }^{71}$ ) would have opened the doors to whoever was in spiritual need.

\section{ii. Schools in Byzantine Cappadocia. Their physical setting}

Athanasios Markopoulos, the researcher mentioned at the outset of the paper (in footnote 3) as commenting on the scarcity of publications (and information in general) concerning the physical setting of schools in Byzantium, states that "Little is known about the places in which [those] were housed." "72 But we also need to underline with the same scholar, that "As many grammatistai were members of the clergy, it is quite likely that lessons were widely conducted in churches or the courtyards of monasteries." ${ }^{, 73}$ With this in mind when, next to the church of St. Stephen, I came across a room from the sixth-seventh centuries that had in

\footnotetext{
${ }^{69}$ Fatma Gül Öztürk, “Açiksaray 'Open Palace': a Byzantine rock-cut settlement in Cappadocia”, Byzantinische Zeitschrift, Bd. 107/2, 2014: I. Abteilung “Açiksaray, p. 788.

${ }^{70}$ Ousterhout, Visualizing Community, p. 406.

${ }^{71}$ Jolivet-Lévy, Les églises byzantines de Cappadoce, p. 13.

${ }^{72}$ Athanasios Markopoulos, "Education”, in Elizabeth Jeffreys, John F Haldon and Robin Cormack, The Oxford handbook of Byzantine studies, Oxford Handbooks in Classics and Ancient History, Oxford: Oxford University Press, 2008, p. 788 [pp. 785-795]; see also A. Markopoulos (ed.), Anonymi professoris epistulae, CFHB vol. XXXVII, Berlin, New York: Walter de Gruyter, 2000, and Michael Jeffreys and Marc D. Lauxtermann (eds)., The Letters of Psellos. Cultural Networks and Historical Realities, Oxford: Oxford University Press, 2017.

${ }^{73}$ A. Markopoulos, "Education", p. 788.
} 
front of it the notice 'Refectory and school'(fig. 12a), despite the caution we are advised to manifest towards local signs, I became alert.

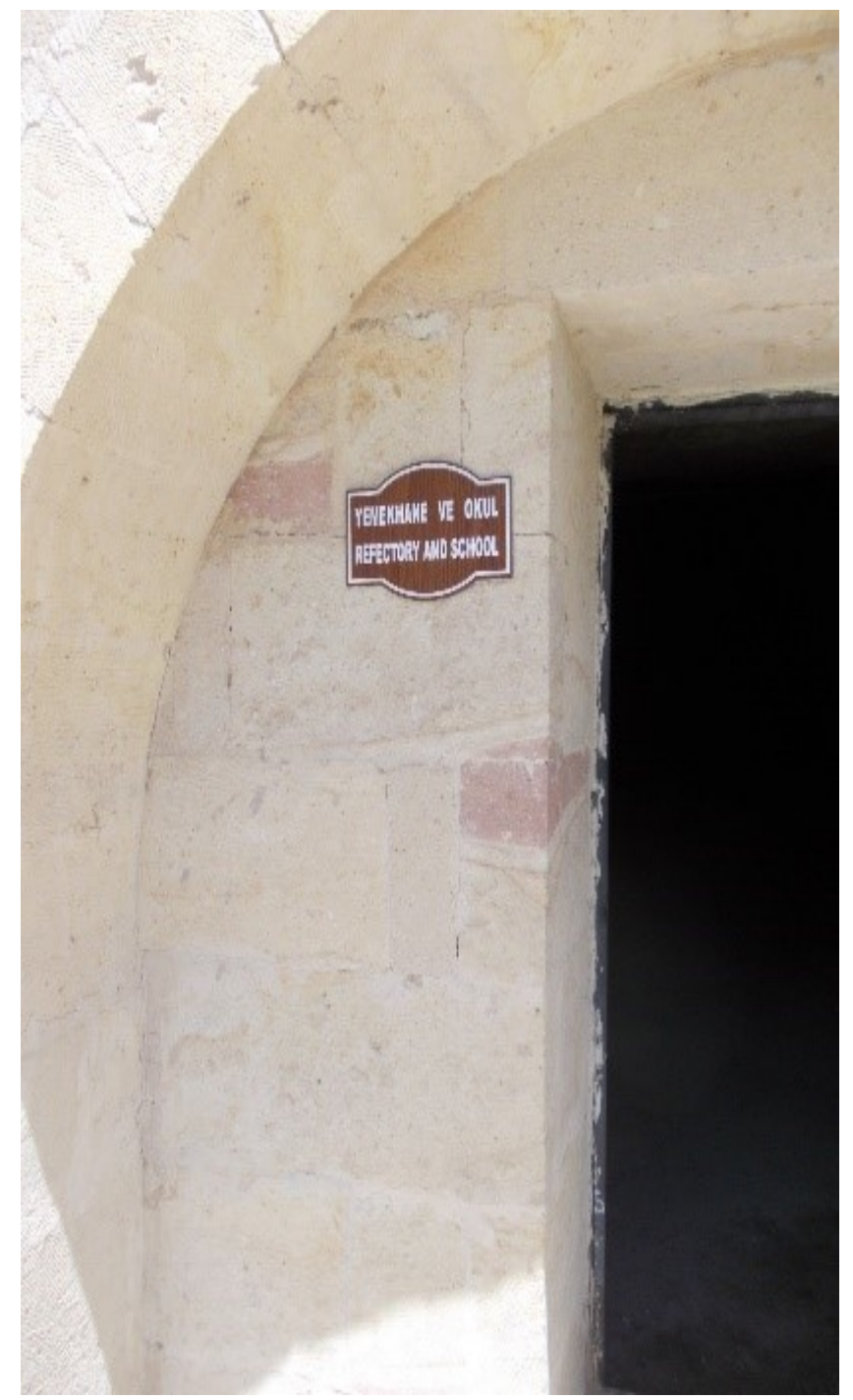

Fig. 12.a) Refectory and school within the dwelling around St. Stephen Church [in the village of Cemil, close to Ürgüp]; sixth-seventh centuries; photos by E.E D-V taken in May 2015.

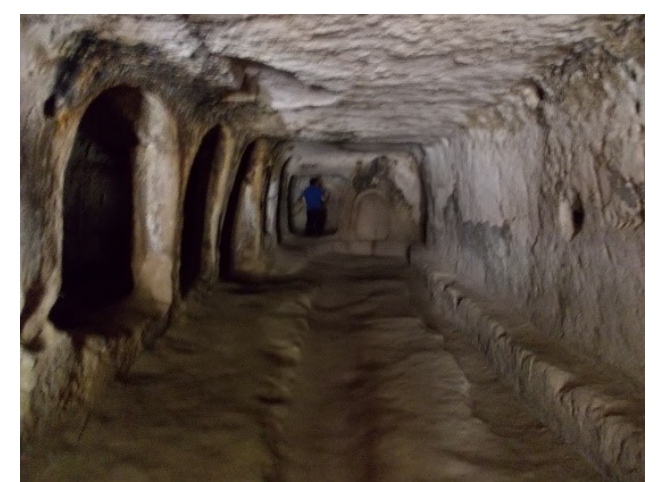

Fig. 12b).View from the interior of the refectory and school within the dwelling around St. Stephen Church; photos by E.E D-V taken in May 2015. 
The arrangement of benches and niches within this space (fig. 12b) allows one to say that it would have been appropriate and convenient for use as a classroom. After reading Libanius's text in which he offers a short account, as further shown, about the physical setting of his school in Antioch, which is not far from Cappadocia (he does it in Oration 22 to Ellebichus) ${ }^{74}$ this enclosure seemed to me to be the closest approximation concerning the layout of such a room in the fourth century Byzantium, the period in which Libanius (314 393/4) lived and wrote. In this text by him, at Or. 22.31, there is a description of the city hall (and of its immediate surrounding), which is significant for our discussion because this is the place in which Libanius held his classes (after he taught for a while in his own home). The government accommodated school is presented thus: "This allowed them [the administrative council of Antioch] the use of the city-hall where there was a covered theatre, and four colonnades with a central courtyard which had been turned into a garden with vines, figs and other trees, and different kinds of green-stuff." "75 From the elements introduced here by this ancient teacher of rhetoric we learn enough to allow ourselves to acknowledge the material similarities between the school building in Antioch and structures around churches in Cappadocia, like those in figs. 12 and 13, which we consider that could have been schools. Despite the fact that what Libanius writes about is a school within a 'proper' town (with an administrative centre and all urban amenities of the fourth century) and what has survived from Cappadocia are constructions from a different milieu and of a later date (nevertheless, the space in St. Steven's complex is only about one hundred years later than the Antiochian teaching area), one can feel justified to assume that the Anatolian buildings in the images below were parts from schools. If we take into consideration the slow pace in the

\footnotetext{
${ }^{74}$ Libanius, Libanius: Selected Orations, edited and translated by Albert Francis Norman, Cambridge, Massachusetts: Loeb Classical Library, vols. 1-2.

${ }^{75}$ Libanius, Oration 22. 31, in Libanius: Selected Orations, vol. 2, p. 399. See also Raffaella Cribiore's comments on the setting of Libanius's school in the book, The School of Libanius in Late Antique Antioch, Princeton: Princeton University Press, p. 48.
} 
development of construction techniques in the area due to the harsh climate Basil of Caesarea speaks about, ${ }^{76}$ a fourth century school in Antioch and a sixth century one in Cappadocia could have not been very different; the images in fig. 13, from Gümusler Monastery, Cappadocia, suggest that the statement can be true even of a thirteenth-century school.
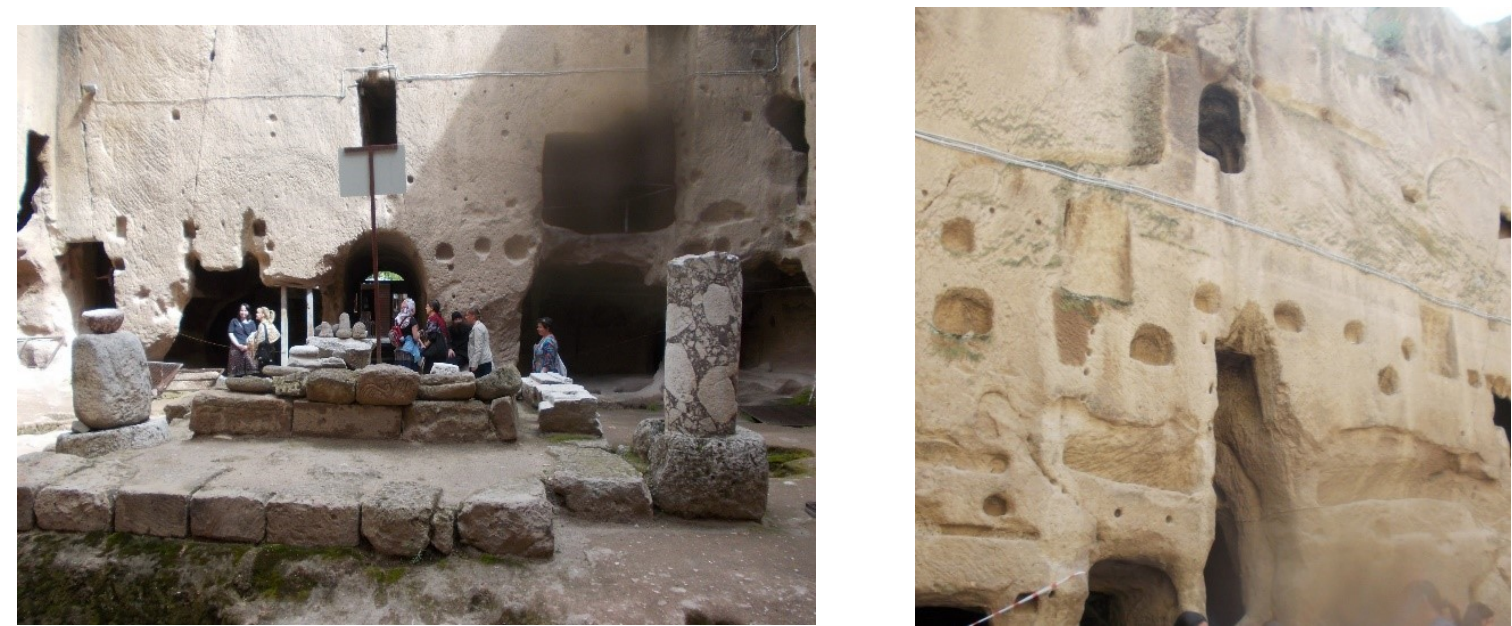

Figs. 13 a, b. Gümusler Monastery, Cappadocia, thirteenth century; photos by E.E D-V taken in May 2015.

\footnotetext{
${ }^{76}$ Basil of Caesarea, Letters 48, 112, 121, 198, 213, 215, 350, in Collected Letters of Saint Basil, edited and trans. by Roy J. Deferrari; in vol. 4, an "Address to young men on reading Greek literature" was translated by Roy J. Deferrari and Martin R. P. McGuire, Cambridge, MA: Harvard University Press, Loeb classical library, 2014, vols. 1-4; vol. 1 (ep. 48; Basil speaks about 'our land' without naming it and about the Cappadocians), pp. 314-315; vol. 2 (ep. 112; here he refers to the Cappadocians), pp. 214-215, (ep. 121), pp. 248-249; vol. 3 (ep. 198), pp. 100-101, (ep. 213), pp. 224-225, (ep. 215), pp. 236-237, (ep. 350), pp. 318-319; Basil of Caesarea, L'Église de Cappadoce au IVe siècle d'après la correspondance de Basile de Césarée (330-379) edited by Benoît Gain, Rome: Orientalia Christiana Analecta, vol. 225, 1985, epistles 48, 112, 121, 198, 213, 350, pp. 1921, 394-96. In most of these letters Basil refers to the bad weather and does not directly names his country, but says 'our land' or names Armenia as a neighbouring territory. See also Basil of Caesarea, Letters, trans. by Roy J. Deferrari, London: Heinemann, 1926-1939; Basil of Caesarea, Epistles, in Philip Schaff, Nicene and Post-Nicene Fathers (second series), vol. 8: Basil: Letters and Select Works, Edinburgh: T\&T Clark, 1895, and Saint Basile lettres, edited by Yves Courtonne, Paris: Société d'édition Les Belles lettres, 1973, vols. 1-3. Further reading Anne Karahan, "Beauty in the Eyes of God. Byzantine Aesthetics and Basil of Caesarea", in Byzantion. Revue Internationale des Études Byzantines 82 (2012): 165-212.
} 


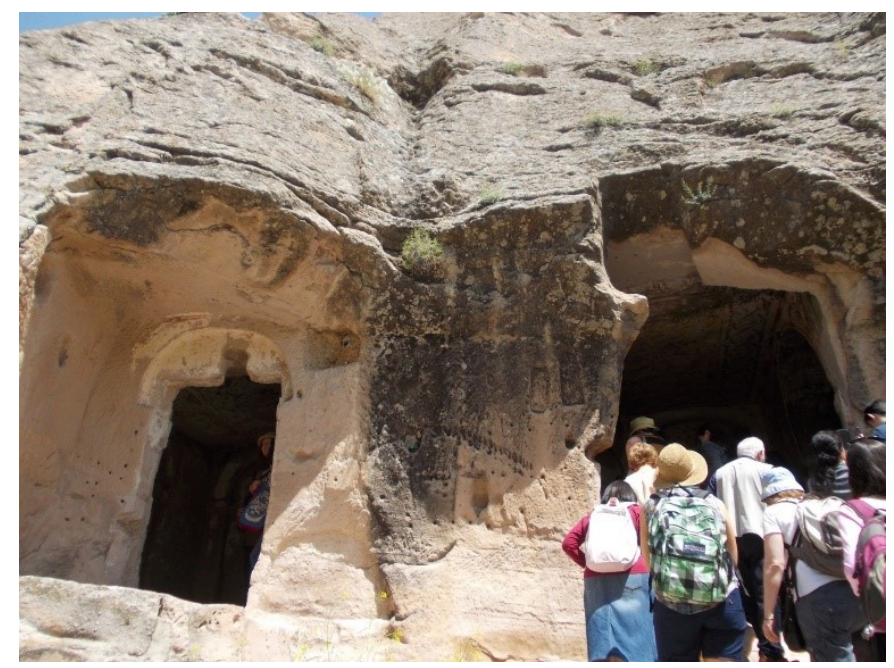

Fig. 14. The image outside the room called 'refectory and school' in St. Stephen's settlement, sixth-seventh centuries (close to Libanius's time).

When reading the commentaries about the educational system in Byzantium made by various researchers ${ }^{77}$ it is also easy to observe the similitudes between today's system of attracting students to the university as well as the practice of writing letters of recommendation and the educational networking in general ${ }^{78}$ and that which existed in Byzantine Cappadocia and Antioch. Likewise, it is noticeable that all these features are essentially the same as those of contemporary to us classrooms and refectories. Also if we look at the images of the numerous refectories that Ousterhout presents within the publication Visualizing Community we observe that all of them look alike the room from St. Stephen's complex (fig. 14). This suggests that many if not all such spaces might have served as schools as well as refectories.

\footnotetext{
${ }^{77}$ Athanasios Markopoulos, "Education", in Elizabeth Jeffreys, John F Haldon and Robin Cormack, The Oxford handbook of Byzantine studies, Oxford Handbooks in Classics and Ancient History, Oxford: Oxford University Press, 2008, p. 788 [pp. 785-795]; see also A. Markopoulos (ed.), Anonymi professoris epistulae, CFHB vol. XXXVII, Berlin, New York: Walter de Gruyter, 2000; R. Cribiore, The School of Libanius in Late Antique Antioch and Gymnastics of the Mind, Princeton: Princeton University Press, 2001; Lieve van Hoof (ed.), Libanius: a critical introduction, Cambridge: Cambridge University Press, 2014; Lieve Van Hoof, "Lobbying through Literature: Libanius, For the Teachers (Oration 31)", in L. Van Hoof and P. Van Nuffelen (eds.), Literature and Society in the Fourth Century A.D.: Performing Paideia, Constructing the Present, Presenting the Self, Leiden: Brill, 2014, pp. 68-82. A project entitled 'Early Monasticism and Classical Paideia' has been undergoing at the University of Lund since 2009. Especially Lillian Larsen's contribution, The Role of Apophthemata Patrum in Teaching, Transmitting, and Transforming School and Civic Rhetoric has connections with my article. I only found about this project in April 2018; I am grateful to Joel Kalvesmaki, Managing Editor in Byzantine Studies at Dumbarton Oaks for drawing my attention to it.

${ }^{78}$ Michael Jeffreys and Marc D. Lauxtermann (eds.), The Letters of Psellos. Cultural Networks and Historical Realities, Oxford: Oxford University Press, 2017.
} 


\section{iii. Conclusion}

By means of conclusion, we can reiterate that the fashion in which the places of human habitation are arranged reveals something of what people had in mind when they initiate their foundations, and that also applies to schools and church buildings, in particular to the Christian shrines considered in this article. These are an expression of the needs and aspirations of the people who both constructed them, attended, and benefitted from their services. Hopefully, the analysis we have undertaken concerning the functionality of the churches in this Byzantine province has shown that the variety in their dimensions, shapes, and decoration would have allowed them to serve both as centres of monastic life and places of worship for laity. Certainly they, and also the schools, were a factor of cohesion for people - and still are so in those places where they are allowed to operate today. Church functionality in Cappadocia shall increase from this perspective when more shrines are reopened (this is happening more frequently now than was the case ten years ago). 


\section{Bibliography}

Attaliotes, M., Historia, ed. by Immanuel Bekker and Charles M Brunet de Presle, Bonn: Weber, 1853

Angold, M. (ed.), The Byzantine Aristocracy IX to Xlll Centuries, Oxford: B.A.R International Series 221, 1984

Balaban Bara, A., The Political and Artistic Program of Prince Petru Rareş of Moldavia, doctoral dissertation, unpublished doctoral dissertation, University of Montreal, 2012

Beard, M. and J. Henderson, "Cappadocians at Court: Diogenes and Timarion", in M. Mullett and D. Smythe (ed.), Alexios l Komnenos, BBTT (Papers of the second Belfast Byzantine International Colloquium, 14-16 April, 1989) 4.1, Belfast, 1996, pp. 329-338

Beaton, R. and D. Ricks, Digenis Akritis: new approaches to Byzantine poetry, Aldershot: Ashgate, 1993, pp. 103-115

Bradbury, S., Selected Letters of Libanius, Liverpool, University Press, 2004

Cameron, A., Byzantine Matters, Princeton: Princeton University Press, 2014

Cameron, A. "Education and literary culture", in A. Cameron, and P. Garnsey (eds.), The Cambridge ancient history: vol. XIII The late empire, A.D. 337-425, Cambridge: Cambridge University Press, 1998, pp. 668-669

Cheynet, J. -C., "L'aristocratie cappadocienne aux Xe et Xle siècles", Dossiers d'Archéologie 233, 2003, pp. $42-49$

Cormack, R., Byzantine Art, Oxford: Oxford University Press, 2000

Cormack, R., "Aristocratic Patronage of the Arts in the $11^{\text {th }}$ and $12^{\text {th }}$ century Byzantium", in M. Angold, (ed.), The Byzantine Aristocracy IX to Xlll Centuries, Oxford: B.A.R International Series 221, 1984, pp. 158-172

Corpus Inscriptionum Graecarum (CIG), initially edited by August Böckh, 1828-1877, vols. $1-13$

Cribiore, R., The School of Libanius in Late Antique Antioch, Princeton: Princeton University Press, 2007

Cribiore, R., Gymnastics of the Mind, Princeton: Princeton University Press, 2001

Decker, M., and J. Eric Cooper, Life and Society in Byzantine Cappadocia, Basingstoke: Palgrave Macmillan, 2012

Dagron G. and H. Mihăescu, Le traité sur la guérilla (De velitatione) de l'empereur Nicéphore Phocas, Paris: Centre National de la Recherche Scientifique, 1986 
Ene D-Vasilescu, E., Heavenly Sustenance in Patristic Texts and Byzantine Iconography. Nourished by the Word, Palgrave, 2018

Ene D-Vasilescu, E. (ed.), Devotion to St. Anne from Byzantium to the Middle Ages, Palgrave, 2018

Ene D-Vasilescu, E., "The 1889 Synod of the Romanian Orthodox Church: a success or a failure in the development of Romanian iconography?", in Cinstirea Sfantelor icoane in Ortodoxie/Honouring the Holy Icons in Orthodoxy, Iaşi: Doxologia, 2008, pp. 355-375

Ertuğ, A., and C. Jolivet-Lévy, Sacred art of Cappadocia: Byzantine murals from the 6th to 13th centuries, Istanbul: Ertuğ \& Kocabıyık, 2006

Festugière, A. J., with a commentary by Roland Martin, Antioche païenne et chrétienne, Libanius. Chrysostome et les moines de Syrie, Paris: E. de Boccard, Bibliothèque des Écoles françaises d'Athènes et de Rome series, fascicule 194), first edition1959

Giovannini, L. (ed.), Arts de Cappadoce, Genève: Nagel, 1971

Grabar, A., Christian iconography: a study of its origins, Routledge and Kegan Paul, London, 1969

Haldon, J. F. and H. Kennedy, "The arab-byzantine frontier in the eighth and ninth centuries: military organisation and society in the borderlands", Zbornik Radova Vizantoloskog Instituta 19 (1980), pp. 79-116

Halporn, B. C., The Correspondence of Johann Amerbach, Ann Arbor: University of Michigan Press, 2000

Hauge, M. R. and A. W. Pitts (eds.), Ancient education and early Christianity, New York: Bloomsbury, 2016

Hendy, M. F. in Studies in the Byzantine monetary economy, c. 300-1450, Cambridge, UK: Cambridge University Press, 1985

Hendy, M.F., "Light Weight Solidi, Tetartera and the Book of the Prefect", Byzantinische Zeitschrift 65 (1972), pp. 57-80

Herrin, J., Byzantium: The Surprising Life of a Medieval Empire, Princeton: Princeton University Press, 2007

Hild, F., and M. Restle, Kappadokien (Kappadokia, Charsianon, Sebasteia und Lykandos) [Tabula Imperii Byzantini 2], Vienna, 1981

Hunt, L-A., "Comnenian Aristocratic Palace Decoration: Descriptions and Islamic connections", in M. Angold, (ed.), The Byzantine Aristocracy IX to Xlll Centuries, Oxford: B. A.R International Series 221, 1984, pp. 138-157

Jeffreys, M. and M. D. Lauxtermann (eds)., The Letters of Psellos. Cultural Networks and Historical Realities, Oxford: Oxford University Press, 2017 
Jeffreys, E., Digenis Akritis: the Grottaferrata and Escorial Versions, Cambridge: Cambridge University Press, 1998

Jeffreys, E., The Homilies of James of Kokkinobaphos in their twelfth-century context, paper presented at the Seventeenth International Conference of Patristic Studies, 2015

Jerphanion, G. de, Un nouvelle province de l'art byzantine. Les églises rupestres $d u$ Cappadoce, Paris: Paul Geuthner, 1925, vol. 1

Jerphanion, G. de, "Mellanges d'archeologie anatolienne: monuments préhelléniques, grécoromains, byzantins et musulmans de Pont, de Cappadoce et de Galatie", MelUSJ Xlll, Beyrouth: Impr. Catholique, 1928

Jolivet-Lévy, C., Études cappadociennes, London: Pindar Press, 2002

Jolivet-Lévy, C., and C. Savageot, La Cappadoce médiévale: images et spiritualité, Zodiaque, Saint-Léger-Vauban, 2001

Jolivet-Lévy C. and C. Savageot, L’arte della Cappadocia, Milano: Jaca Book, 2001

Jolivet-Lévy, C., Les églises byzantines de Cappadoce: le programme iconographique de l'abside et de ses abords, Paris: Éditions du Centre national de la Recherche scientifique CNRS, 1991

Kalas, V., "Early Explorations of Cappadocia and the Monastic Myth", in Byzantine and Modern Greek Studies 28, 2004, pp. 101-119

Kalas, V. "Challanging the Sacred Landscape of Byzantine Cappadocia", in A. Walker and A. Luyster (eds.), Negotiating Secular and Sacred in Medieval Art, Ashgate, Aldershot, 2009, $147-173$

Kalas, V., "Cappadocia”, Encyclopedia of Monasticism, in W. M. Johnson, Chicago, 2000, pp. 238-239

Kalas, V., "Rock-Cut Architecture of the Peristrema Valley: Society and Settlement in Byzantine Cappadocia", doctoral dissertation, New York University, New York, 2000

Kaplan, M., "Les grand proprietaries du Cappadoce (Vl- Vlle siècle)", in C. D. Fonseca (ed.), Le aree omogeneé della civiltà rupestre nell'ambito dell'Impero bizantino: La Cappadocia, Galatina, 1981, pp. 125-158

Kazhdan, A. (ed.), Oxford Dictionary of Byzantium, New York and Oxford: Oxford University Press, 1991, vols. 1-3

Kitzinger, E., "Byzantine art in the period between Justinian and iconoclasm," in Les Actes du Xl e Congress International d'Études bizantines, Münich, 1958, pp. 1-50

Koder, J. (ed. and trans.), Das Eparchenbuch Leons des Weisen, Verlag der Österreichischen Akademie der Wissenschaften, Vienna, 1991 
Kostof, S., Caves of God. The Monastic Environment of Byzantine Cappadocia, Cambridge, Mass., 1972 (éd. révisée sous le titre Caves of God. Cappadocia and its Churches, Oxford/ New York/Toronto, 1989

Lafontaine-Dosogne, J., Iconographie de l'enfance de la Vierge dans l'empire byzantin et en Occident, Brussels, 1964, vols. 1-2

Laiou, A. E. (editor-in-chief), Charalambos Bouras, et al., The Economic History of Byzantium: from the seventh through the fifteenth century, Dumbarton Oaks Studies 46, Washington D.C.: Dumbarton Oaks Research Library and Collection and Harvard University Press, Dumbarton Oaks Studies 39, 2002, vols. 1-3,

Laiou, A. E and Cécile Morrison, The Byzantine Economy, Cambridge, UK: Cambridge University Press, 2007

Libanius, Libanius: Selected Orations, edited and translated by A. F. Norman, Cambridge, Massachusetts: Loeb Classical Library, vols. 1-2, 1969-1977

Libanius, Libanius: Autobiography and Selected Letters, edited and translated by A.F. Norman, Cambridge, Massachusetts: Loeb Classical Library, vols. 1-2, 1992

Libanius, Libanius' Autobiography (Oration 1), edited by A.F. Norman, London, New York, Toronto: Oxford University Press, 1965

Magdalino, P., "The Byzantine Aristocratic Oikos", in M. Angold, (ed.), The Byzantine Aristocracy IX to Xlll Centuries, Oxford: B. A.R9 International Series 221, 1984, pp. 92-112

Mango, C., The Art of the Byzantine Empire, 312-1453: Sources and Documents, Englewood Cliffs, N.J: Prentice-Hall; reprinted by University of Toronto Press, Toronto, Buffalo and London, 1972 and 1986

Maniatis, G. C., "The Domain of the Private Guilds in the Byzantine Economy. Tenth to Fifteenth Centuries", Dumbarton Oaks Papers, 55, 2001, pp. 339-369

Markopoulos, A (ed.), Anonymi professoris epistolae, Berlin, New York: Walter de Gruyter, (Corpus Fontium Historiae Byzantinae. Series Berolinensis 37), 2000

Mateo-Seco, L. F. \& G. Maspero (eds.), The Brill Dictionary of Gregory of Nyssa, Leiden, Boston: Brill, 2010

Mundell Mango, M., "The Commercial Map of Constantinople”, Dumbarton Oaks Papers, 54, 2000, pp. 189-207

Nicole, J., E. Hanson Freshfield, and I. Duĭchev (eds.), To eparchikon vivlion/Livre du préfet/The book of the Eparch, London: Variorum Reprints, 1970

Oikonomides, N., "St. George of Mangana, Maria Skleraina, and the 'Malyj Sion' of Novgorod", Dumbarton Oaks Papers 34-35 (1980-1), p. 241 [pp. 239-246] 
Ousterhout, R. G., Visualizing Community: Art, Material Culture, and Settlement in Byzantine Cappadocia, Dumbarton Oaks Studies 46, Washington D.C.: Dumbarton Oaks Research Library and Collection and Harvard University Press, 2017

Ousterhout, R. G., A Byzantine Settlement in Cappadocia, Dumbarton Oaks Studies 42, Washington, D.C.: Dumbarton Oaks Research Library and Collection and Harvard University Press, revised edition 2011

Psellos, M., Chronographie ou Histoire d'un siècle de Byzance (976-1077), trans. Emile Renauld, Paris: Les Belles-Lettres, 1928

Silvas, A. M. (ed.), Gregory of Nyssa. The Letters: Introduction, translation and commentary, Leiden, Boston: Brill, Supplements to Vigiliae Christianae 83, 2007

Skylitzes, J., Synopsis historiarum, ed. by Hans Thurn, Berlin-New York: De Gruyter, CFHB 5, 1973, 476-477 (trans. by J. Wortley as A Synopsis of Byzantine History, 2010)

Thierry, N., La Cappadoce de l'antiquité au Moyen Âge, Brepols, Turnhout (Bibliothèque de l'Antiquité tardive 4), 2002

Underwood, P.1 A., The Kariye Djami, Bollingen Series LXX, Pantheon Books, New York, 1966, vols. 1-2

Wharton-Epstein, A., "Rock-cut chapels in Göreme Valley, Cappadocia: the Yilanli group and the column churches," Cahiers archéologiques. Fin de l'antiquité et moyen-âge, vol. 24 (1975), pp. 115-135

Zonaras, J., Epitomae historiarum, edited by T. Biittner-Wobst, Bonn: CSHB, 1897, III, 61920, 646, 647 (in English, The History of Zonaras from Alexander Severus to the Death of Theodosius the Great, edited and trans. by Thomas Banchich and Eugene Lane, London: Routledge 2009). 